\title{
Actinopolymorpha cephalotaxi sp. nov., a novel actinomycete isolated from rhizosphere soil of the plant Cephalotaxus fortunei
}

\author{
Correspondence \\ Wen-Jun Li \\ wjli@ynu.edu.cn \\ Yue-Qin Zhang \\ zyq_0525@yahoo.com.cn
}

\author{
Li-Jie Yuan, ${ }^{1,2} \uparrow$ Yu-Qin Zhang, ${ }^{1} \dagger \mathrm{Li}-\mathrm{Yan} \mathrm{Yu},{ }^{1}$ Cheng-Hang Sun, ${ }^{1}$ \\ Yu-Zhen Wei, ${ }^{1}$ Hong-Yu Liu, ${ }^{1}$ Wen-Jun $\mathrm{Li}^{3}$ and Yue-Qin Zhang ${ }^{1}$
}

\author{
${ }^{1}$ Institute of Medicinal Biotechnology, Chinese Academy of Medical Sciences and Peking Union \\ Medical College, Beijing 100050, PR China \\ ${ }^{2}$ Department of Biology, North China Coal Medical College, Tangshan, Hebei 063000, PR China \\ ${ }^{3}$ The Key Laboratory for Microbial Resources of the Ministry of Education, PR China and Laboratory \\ for Conservation and Utilization of Bio-Resources, Yunnan Institute of Microbiology, Yunnan \\ University, Kunming, Yunnan 650091, PR China
}

\begin{abstract}
An actinomycete, strain $106-2230^{\top}$, was isolated from rhizosphere soil of the plant Cephalotaxus fortunei, collected from Yunnan province, south China. Phylogenetic analysis based on 16S rRNA gene sequences indicated that the isolate belongs to the genus Actinopolymorpha. Cells grew on agar surfaces, with no penetration even after prolonged cultivation. Aerial hyphae were absent. Cells were irregularly shaped and remained attached as chains or aggregates. Chemotaxonomic data, which showed LL-diaminopimelic acid in the cell wall, glucose as the whole-cell sugar, type PI phospholipids and MK- $9\left(\mathrm{H}_{4}\right)$ as the predominant menaquinone, supported the affiliation of strain $106-2230^{\top}$ to the genus Actinopolymorpha. The major fatty acids were iso- $\mathrm{C}_{15: 0,}$, iso- $\mathrm{C}_{16: 0}$ and iso- $\mathrm{C}_{16: 1} \mathrm{H}$. The genomic DNA G+C content was $69.3 \mathrm{~mol} \%$. DNA-DNA hybridization data, in combination with chemotaxonomic, physiological and biochemical data, demonstrated that strain 106-2230 ${ }^{\top}$ should be classified as representing a novel species of the genus Actinopolymorpha. The name Actinopolymorpha cephalotaxi sp. nov. is proposed, with strain I06$2230^{\top}$ (=DSM $45117^{\top}=\mathrm{CCM} 7466^{\top}=$ KCTC $19293^{\top}$ ) as the type strain.
\end{abstract}

The genus Actinopolymorpha was first proposed by Wang et al. (2001) to accommodate a highly pleomorphic and considerably salt-tolerant actinomycete with LL-diaminopimelic acid in the cell wall, type PI phospholipids and MK-9 $\left(\mathrm{H}_{6}\right)$ as the predominant menaquinone. At the time of writing, the genus comprised two species with validly published names, Actinopolymorpha singaporensis (Wang et al., 2001) and Actinopolymorpha rutila (Wang et al., 2008).

During our screening research on the plant rhizosphere microbial flora of China, strain I06-2230 ${ }^{\mathrm{T}}$ was recovered and its taxonomic position was investigated using a polyphasic approach. Strain I06-2230 ${ }^{\mathrm{T}}$ was isolated from rhizosphere soil of Cephalotaxus fortunei, collected from Yunnan province, south China, using the dilution plating method and incubation at $28{ }^{\circ} \mathrm{C}$ for 21 days. The medium

†These authors contributed equally to this work.

The GenBank/EMBL/DDBJ accession number for the 16S rRNA gene sequence of strain 106-2230 ${ }^{\top}$ is EU438909.

Scanning electron micrographs and a table of cellular fatty acid contents are available as supplementary material with the online version of this paper. used for selective isolation contained $\left(1^{-1}\right): 5 \mathrm{~g}$ starch, $5 \mathrm{~g}$ glycerol, $1 \mathrm{~g}$ proline, $1 \mathrm{~g}\left(\mathrm{NH}_{4}\right)_{2} \mathrm{SO}_{4}, 1 \mathrm{~g} \mathrm{NaCl}, 2 \mathrm{~g} \mathrm{CaCl}_{2}$, $1 \mathrm{~g} \mathrm{~K}_{2} \mathrm{HPO}_{4}, 1 \mathrm{~g} \mathrm{MgSO}_{4} \cdot 7 \mathrm{H}_{2} \mathrm{O}, 50 \mathrm{mg} \mathrm{K} \mathrm{Cr}_{2} \mathrm{O}_{7}, 25 \mathrm{mg}$ aztreonam and $15.0 \mathrm{~g}$ agar and had a final $\mathrm{pH}$ 7.2. The strain was maintained on ISP 2 agar slants (Shirling \& Gottlieb, 1966) at $4{ }^{\circ} \mathrm{C}$ and stored as $20 \%(\mathrm{w} / \mathrm{v})$ glycerol suspensions at $-20{ }^{\circ} \mathrm{C}$. Biomass for chemical and molecular systematic studies was obtained by cultivation in shake flasks (160 r.p.m.) using tryptic soy broth (TSB; Difco) at $28{ }^{\circ} \mathrm{C}$ for 6 days.

For the observation of colony and cultural characteristics, ISP 2, 3, 4 and 5 agar (Shirling \& Gottlieb, 1966), Czapek's solution agar (Waksman, 1961), nutrient agar (Difco) and tomato paste-oatmeal agar (Waksman, 1961) were inoculated with strain $\mathrm{I} 06-2230^{\mathrm{T}}$. Cultures were incubated at $28{ }^{\circ} \mathrm{C}$ and observations were recorded after 7, 14, 21 and 28 days. For cell morphology, the coverslip technique, as described by Kawato \& Shinobu (1959), was used on ISP 2 agar. Some gold-coated dehydrated specimens of 14-day cultures were observed by using scanning electron microscopy (Quanta; FEI). Strain I06-2230 ${ }^{\mathrm{T}}$ grew well on agar surfaces, but without penetration even after prolonged 
cultivation. Aerial hyphae were absent. The colonies were paste-like and initially smooth and later wrinkled. Irregular cells were observed (Supplementary Fig. S1, available in IJSEM Online). Cells appeared to divide through apical and lateral budding and remained attached after division, often forming short chains and small aggregates. The colour of the colonies on ISP 3, 4 and 5 agar, Czapek's solution agar, nutrient agar and tomato paste-oatmeal agar was buff or yellow and on ISP 2 agar was brilliant orange. Buff diffusible pigment was produced on ISP 3 agar, nutrient agar and tomato paste-oatmeal agar.

Carbohydrate utilization and enzyme activities were determined using the API $50 \mathrm{CH}$ and API ZYM systems (bioMérieux), respectively, according to the manufacturer's instructions, after growth at 4, 10, 20, 28-37 (with intervals of $1{ }^{\circ} \mathrm{C}$ ), 40 and $45{ }^{\circ} \mathrm{C}$ on ISP 2 agar for 15 30 days. The ability of the strain to grow at different $\mathrm{NaCl}$ concentrations $(0,1,3,5-20 \%$, with intervals of $0.5 \%$, w/v) was determined according to Wang et al. (2001). pH tolerance ( $\mathrm{pH} 5.0-11.0$, with intervals of $0.5 \mathrm{pH}$ units) was examined with TSB medium. Other physiological and biochemical tests were performed according to the established methods of Williams et al. (1983) and Kämpfer et al. (1991). Good growth occurred at $20-28{ }^{\circ} \mathrm{C}$ and no growth occurred at $4{ }^{\circ} \mathrm{C}$ or above $37{ }^{\circ} \mathrm{C}$. Growth was observed at initial $\mathrm{pH}$ values between $\mathrm{pH} 6.0$ and 8.0 and on TSB medium containing $0-5 \% \mathrm{NaCl}$. Physiological features that differentiate the novel isolate from A. rutila YIM $45725^{\mathrm{T}}$ and A. singaporensis KCTC $19907^{\mathrm{T}}$ are given in Table 1 and other phenotypic characteristics are presented in the species description.

The whole-cell sugar composition and diagnostic isomers of diaminopimelic acid were analysed by TLC as described by Lechevalier \& Lechevalier (1980). Menaquinones were extracted by using the method of Collins (1985) and analysed by HPLC (Groth et al., 1997). The phospholipids were extracted, examined by two-dimensional TLC and identified as described by Minnikin et al. (1984). The fatty acids were prepared and analysed according to the instructions of the standard Sherlock Microbial Identification system (Sasser, 1990; Kämpfer \& Kroppenstedt, 1996). Strain I06-2230 ${ }^{\mathrm{T}}$ contained LLdiaminopimelic acid as the diamino acid and glucose as the whole-cell sugar. The phospholipids comprised phosphatidylinositol, phosphatidylglycerol and phosphatidylinositol mannosides. The predominant menaquinone was MK-9 $\left(\mathrm{H}_{4}\right)$. Small amounts of MK-9 $\left(\mathrm{H}_{6}\right)$, MK-9 $\left(\mathrm{H}_{8}\right)$ and MK-10 $\left(\mathrm{H}_{4}\right)$ were also present. The major fatty acids were

Table 1. Differential characteristics of strain $106-2230^{\top}$ and its closest phylogenetic neighbours

Strains: 1, I06-2230 ${ }^{\mathrm{T}}$ (Actinopolymorpha cephalotaxi sp. nov.); 2, A. rutila YIM 45725 ${ }^{\mathrm{T}} ; 3$, A. singaporensis KCTC $19907^{\mathrm{T}}$. Data were taken from this study. All strains were positive for utilization of D-fructose, D-galactose, $\alpha$-D-glucose, D-mannitol, L-rhamnose, sucrose, D-xylose, $m y o$-inositol and sorbitol and hydrolysis of gelatin. All strains were negative for starch degradation and were sensitive to $0.1 \%$ phenol. + , Positive; - , negative.

\begin{tabular}{|c|c|c|c|}
\hline Characteristic & 1 & 2 & 3 \\
\hline Penetrative growth of vegetative hyphae (ISP 3 agar) & - & - & + \\
\hline Aerial hyphae (ISP 2 agar) & - & + & - \\
\hline \multicolumn{4}{|l|}{ Growth conditions } \\
\hline Temperature $\left({ }^{\circ} \mathrm{C}\right)$ & $20-28$ & $15-37$ & $25-37$ \\
\hline $\mathrm{NaCl}$ maximum $(\%)$ & 5 & 5 & 15 \\
\hline \multicolumn{4}{|l|}{ Utilization of: } \\
\hline D-Arabinose & + & + & - \\
\hline Glucosamine & + & + & - \\
\hline Raffinose & + & + & - \\
\hline Nitrate reduction & + & - & + \\
\hline Milk coagulation and peptonization & + & - & + \\
\hline \multicolumn{4}{|l|}{ Acid production from: } \\
\hline Glucose & - & + & - \\
\hline Lactose $(5 \%)$ & - & + & + \\
\hline D-Ribose & - & + & + \\
\hline \multicolumn{4}{|l|}{ Enzyme activities } \\
\hline Esterase & + & - & - \\
\hline Esterase lipase & + & - & + \\
\hline Urease & + & - & - \\
\hline Whole-cell sugars & Glucose & Ribose, galactose, glucose & Rhamnose, ribose, glucose \\
\hline Phospholipids* & PI, PG, PIM & PI, PG, PIM, DPG & PI, PG, PIM, DPG \\
\hline Predominant menaquinone & MK-9 $\left(\mathrm{H}_{4}\right)$ & MK- $9\left(\mathrm{H}_{4}\right)$ & MK-9 $\left(\mathrm{H}_{6}\right)$ \\
\hline
\end{tabular}

^PI, Phosphatidylinositol; PG, phosphatidylglycerol; PIM, phosphatidylinositol mannosides; DPG, diphosphatidylglycerol. 
iso- $\mathrm{C}_{16: 1} \mathrm{H}(32.9 \%)$, iso- $\mathrm{C}_{16: 0}(21.4 \%)$ and iso- $\mathrm{C}_{15: 0}$ $(12.0 \%)$. The detailed profile is given in Supplementary Table S1 (in IJSEM Online).

Genomic DNA extraction and PCR amplification of the $16 \mathrm{~S}$ rRNA gene sequence were performed according to the procedure described by Xu et al. (2003). Purified PCR products were sequenced with an automatic sequencer (ABI PRISM 3730 XL; Applied Biosystems). The almost-complete $16 \mathrm{~S}$ rRNA gene sequence of strain $\mathrm{I}) 6-2230^{\mathrm{T}}(1441 \mathrm{bp})$ was aligned with Actinopolymorpha nucleotide sequences retrieved from GenBank using CLUSTAL x version 1.8 (Thompson et al., 1997). Subsequently, a phylogenetic tree was constructed using MEGA version 2.1 (Kumar et al., 2001). Distances were calculated using distance options according to the Kimura two-parameter model (Kimura, 1980, 1983) and clustering was performed with the neighbour-joining method of Saitou \& Nei (1987). Bootstrap resampling analysis, according to the method of Felsenstein (1985), with 1000 resamplings was used to evaluate the phylogenetic tree topology. The 16S rRNA gene sequence comparisons clearly showed that strain $\mathrm{I06}-2230^{\mathrm{T}}$ was a member of the family Nocardioidaceae. Strain $\mathrm{I} 06-2230^{\mathrm{T}}$ was phylogenetically closely related to $A$. rutila YIM $45725^{\mathrm{T}}$ and A. singaporensis KCTC $19907^{\mathrm{T}}$, with $16 \mathrm{~S}$ rRNA gene sequence similarity values of 99.5 and $98.9 \%$, respectively, which indicated the affiliation of strain $\mathrm{I} 06-2230^{\mathrm{T}}$ to the genus Actinopolymorpha. Strain $\mathrm{I} 06-2230^{\mathrm{T}}$ formed a distinct branch with A. rutila YIM $45725^{\mathrm{T}}$ in the family Nocardioidaceae in the neighbourjoining phylogenetic tree (Fig. 1).

DNA-DNA hybridizations between strain $106-2230^{\mathrm{T}}$ and A. rutila YIM $45725^{\mathrm{T}}$ and A. singaporensis KCTC $19907^{\mathrm{T}}$ were performed to confirm whether the isolate represented a novel species. The thermal renaturation method (De Ley et al., 1970) was used, with a UV-1700 spectrophotometer (Shimadzu) equipped with a DCW-2008 thermo bath. The DNA-DNA relatedness values between strain $\mathrm{I} 06-2230^{\mathrm{T}}$ and A. rutila YIM $45725^{\mathrm{T}}$ and A. singaporensis KCTC $19907^{\mathrm{T}}$ were $33.81 \%$ and $9.13 \%$, respectively, which were much lower than $70 \%$, the threshold value considered for the delineation of genomic species (Wayne et al., 1987). Therefore, the strain could not be classified in any of the recognized species of the genus Actinopolymorpha. The genomic DNA G + C content of strain $\mathrm{I} 06-2230^{\mathrm{T}}$ was determined using the thermal denaturation $\left(T_{\mathrm{m}}\right)$ method (Marmur \& Doty, 1962) with Escherichia coli AS1.365 as a control. The DNA G+C content was $69.3 \mathrm{~mol} \%$.

On the basis of the phenotypic and genotypic data presented above, we propose that strain I06-2230 represents a novel species of the genus Actinopolymorpha, for which the name Actinopolymorpha cephalotaxi sp. nov. is proposed.

\section{Description of Actinopolymorpha cephalotaxi sp. nov.}

Actinopolymorpha cephalotaxi (ce.pha.lo.ta'xi. N.L. gen. n. cephalotaxi of Cephalotaxus, isolated from Cephalotaxus fortunei from which the rhizosphere soil sample was collected).

Gram-positive. Strictly aerobic. Tolerates up to $5 \% \mathrm{NaCl}$ on TSB medium and ISP 2 medium. Growth occurs at $\mathrm{pH}$ 6.0-8.0 and $20-28{ }^{\circ} \mathrm{C}$. Cells show irregular shapes.

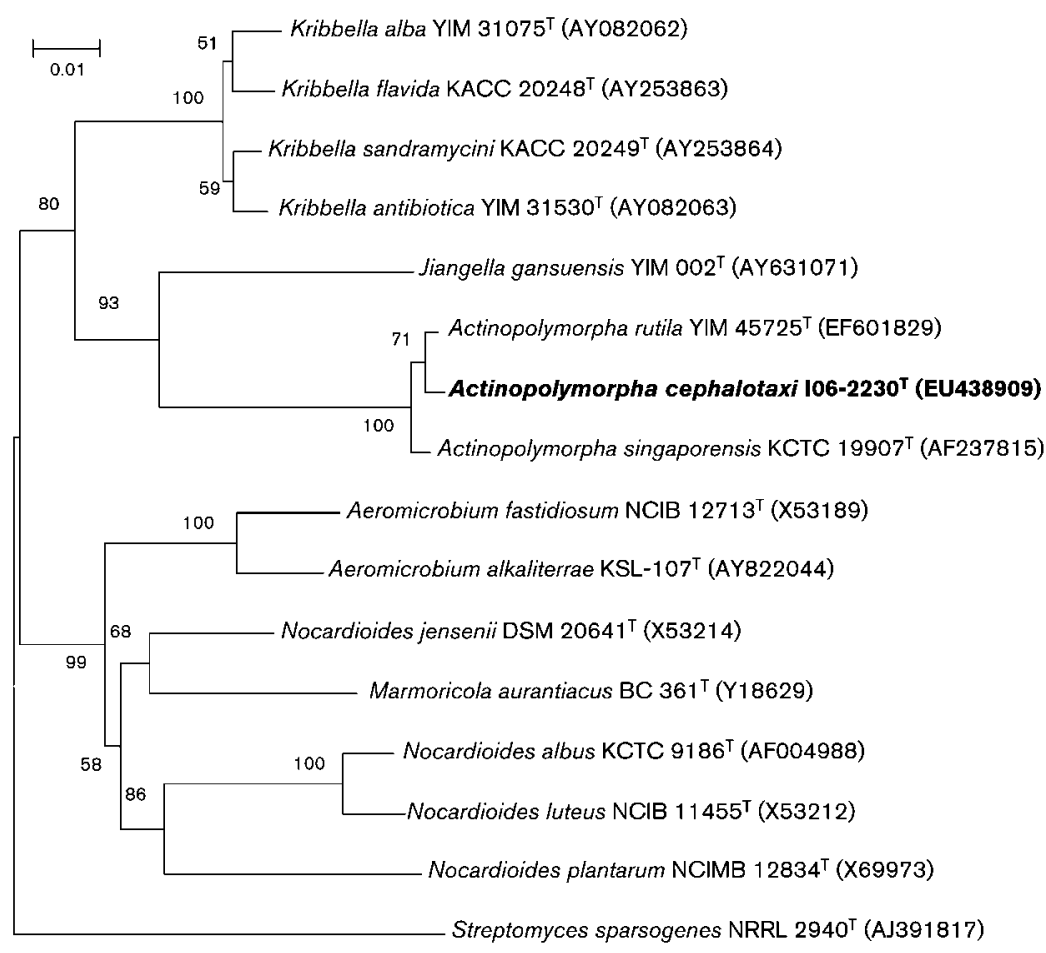

Fig. 1. Phylogenetic dendrogram obtained by distance matrix analysis of $16 \mathrm{~S}$ rRNA gene sequences, showing the position of strain 106$2230^{\top}$ among its phylogenetic neighbours. Bootstrap values $(>50 \%)$ based on 1000 resamplings are shown at branch nodes. Bar, $1 \%$ sequence divergence. 
Cells appear to divide through apical and lateral budding and remain attached after division, often forming short chains and small aggregates. Aerial mycelia are absent on the tested media. Vegetative mycelia develop on agar surfaces. Colonies are paste-like, with buff or yellow colour on most tested media and brilliant orange on ISP 2 medium. Buff diffusible pigment is produced on ISP 3 agar, nutrient agar and tomato paste-oatmeal agar. Utilizes D-arabinose, D-fructose, D-galactose, D-mannitol, raffinose, D-xylose, glucosamine, L-rhamnose, myo-inositol, sorbitol, sucrose and $\alpha$-D-glucose as sole carbon sources, but not acetate, citrate, gluconate, mucic acid or tartrate. Positive for gelatin hydrolysis, milk coagulation and peptonization and nitrate reduction, but negative for starch degradation, $\mathrm{H}_{2} \mathrm{~S}$ production and cellulose hydrolysis. Sensitive to $0.1 \%$ phenol. Positive for alkaline phosphatase, esterase, esterase lipase, urease, trypsin, chymotrypsin, acid phosphatase, naphthol-AS-BI-phosphohydrolase, $\alpha$ - and $\beta$-galactosidases, $\alpha$ - and $\beta$-glucosidases, $N$-acetyl- $\beta$-glucosaminidase and $\alpha$-mannosidase. The cell wall contains LL-diaminopimelic acid as the diamino acid in the peptidoglycan, without a diagnostic sugar. MK- $9\left(\mathrm{H}_{4}\right)$ is the predominant menaquinone; MK-9 $\left(\mathrm{H}_{6}\right)$, MK-9 $\left(\mathrm{H}_{8}\right)$ and MK-10 $\left(\mathrm{H}_{4}\right)$ also can be detected. Phosphatidylinositol, phosphatidylglycerol and phosphatidylinositol mannosides (type PI phospholipids) are present. Major cellular fatty acids $(>10 \%)$ are iso- $\mathrm{C}_{16: 1} \mathrm{H}$, iso- $\mathrm{C}_{16: 0}$ and iso- $\mathrm{C}_{15: 0}$. The genomic DNA $\mathrm{G}+\mathrm{C}$ content of the type strain is $69.3 \mathrm{~mol} \%$.

The type strain, $\quad \mathrm{I} 06-2230^{\mathrm{T}} \quad\left(=\mathrm{DSM} \quad 45117^{\mathrm{T}}=\mathrm{CCM}\right.$ $7466^{\mathrm{T}}=$ KCTC $19293^{\mathrm{T}}$ ), was isolated from rhizosphere soil of the plant Cephalotaxus fortunei, collected from Yunnan province, south China.

\section{Acknowledgements}

This research was supported by National Facilities and Information Infrastructure for Science and Technology (grant no. 2005DKA21203) and the National Natural Science Foundation of China (NSFC) (grant nos. 30570040, 30600001 and 3010001).

\section{References}

Collins, M. D. (1985). Isoprenoid quinone analysis in classification and identification. In Chemical Methods in Bacterial Systematics, pp. 267-287. Edited by M. Goodfellow \& D. E. Minnikin. London: Academic Press.

De Ley, J., Cattoir, H. \& Reeynaerts, A. (1970). The quantitative measurement of DNA hybridization from renaturation rates. Eur $J$ Biochem 12, 133-142.

Felsenstein, J. (1985). Confidence limits on phylogenies: an approach using the bootstrap. Evolution 39, 783-791.

Groth, I., Schumann, P., Rainey, F. A., Martin, K., Schuetze, B. \& Augsten, K. (1997). Demetria terragena gen. nov., sp. nov., a new genus of actinomycetes isolated from compost soil. Int J Syst Bacteriol 47, 1129-1133.

Kämpfer, P. \& Kroppenstedt, R. M. (1996). Numerical analysis of fatty acid patterns of coryneform bacteria and related taxa. Can J Microbiol 42, 989-1005.
Kämpfer, P., Kroppenstedt, R. M. \& Dott, W. (1991). A numerical classification of the genera Streptomyces and Streptoverticillium using miniaturized physiological tests. J Gen Microbiol 137, 18311891.

Kawato, M. \& Shinobu, R. (1959). On Streptomyces herbaricolor sp. nov., supplement: a single technique for microscopical observation. Mem Osaka Unit Lib Arts Educ B Nat Sci 8, 114-119.

Kimura, M. (1980). A simple method for estimating evolutionary rates of base substitutions through comparative studies of nucleotide sequence. J Mol Evol 16, 111-120.

Kimura, M. (1983). The Neutral Theory of Molecular Evolution. Cambridge: Cambridge University Press.

Kumar, S., Tamura, K., Jakobsen, I. B. \& Nei, M. (2001). MEGA2: Molecular Evolutionary Genetics Analysis software. Bioinformatics 17, 1244-1245.

Lechevalier, M. P. \& Lechevalier, H. A. (1980). The chemotaxonomy of actinomycetes. In Actinomycete Taxonomy, Special Publication 6, pp. 227-291. Edited by A. Dietz \& D. W. Thayer. Arlington, VA: Society for Industrial Microbiology.

Marmur, J. \& Doty, P. (1962). Determination of base composition of deoxyribonucleic acid from its denaturation temperature. J Mol Biol 5, 109-118.

Minnikin, D. E., O'Donnell, A. G., Goodfellow, M., Alderson, G., Athalye, M., Schaal, A. \& Parlett, J. H. (1984). An integrated procedure for the extraction of bacterial isoprenoid quinones and polar lipids. J Microbiol Methods 2, 233-241.

Saitou, N. \& Nei, M. (1987). The neighbor-joining method: a new method for reconstructing phylogenetic trees. Mol Biol Evol 4, 406425.

Sasser, M. (1990). Identification of bacteria by gas chromatography of cellular fatty acids, MIDI Technical Note 101. Newark, DE: MIDI Inc.

Shirling, E. B. \& Gottlieb, D. (1966). Methods for characterization of Streptomyces species. Int J Syst Bacteriol 16, 313-340.

Thompson, J. D., Gibson, T. J., Plewniak, F., Jeanmougin, F. \& Higgins, D. G. (1997). The CLUSTAL_X windows interface: flexible strategies for multiple sequence alignment aided by quality analysis tools. Nucleic Acids Res 25, 4876-4882.

Waksman, S. A. (1961). The Actinomycetes, vol. 2. Classification, Identification and Descriptions of Genera and Species. Baltimore: Williams \& Wilkins.

Wang, Y. M., Zhang, Z. S., Xu, X. L., Ruan, J. S. \& Wang, Y. (2001). Actinopolymorpha singaporensis gen. nov., sp. nov., a novel actinomycete from the tropical rainforest of Singapore. Int J Syst Evol Microbiol 51, 467-473.

Wang, Y. X., Zhang, Y. Q., Xu, L. H. \& Li, W. J. (2008). Actinopolymorpha rutila sp. nov. isolated from a forest soil. Int $J$ Syst Evol Microbiol 58, 2443-2446.

Wayne, L. G., Brenner, D. J., Colwell, R. R., Grimont, P. A. D., Kandler, O., Krichevsky, M. I., Moore, L. H., Moore, W. E. C., Murray, R. G. E. \& other authors (1987). International Committee on Systematic Bacteriology. Report of the ad hoc committee on reconciliation of approaches to bacterial systematics. Int J Syst Bacteriol 37, 463464.

Williams, S. T., Goodfellow, M., Alderson, G., Wellington, E. M. H., Sneath, P. H. A. \& Sackin, M. J. (1983). Numerical classification of Streptomyces and related genera. J Gen Microbiol 129, 1743-1813.

Xu, P., Li, W. J., Xu, L. H. \& Jiang, C. L. (2003). A microwave-based method for genomic DNA extraction from actinomycetes. Microbiology [English translation of Microbiology (Beijing)] 30, 82-84. 